\title{
Fixing a Physics Culture Problem
}

\section{Efforts to improve the climate for women in physics departments take many forms. None should focus on changing its women, some physicists}

say.

\section{By Leto Sapunar}

A few years ago, while listening to a "well-meaning" talk at an annual meeting of the European Astronomical Society, Karina Voggel, an astrophysicist at the Strasbourg Astronomical Observatory, France, came to a realization. The talk provided tips on surviving academia as a woman; her insight-telling women how to fit into the existing academic system is a fundamentally flawed route to keeping women in the field. This method, she says, puts the pressure on women to adapt while leaving the system-and its problems-completely unchanged.

In the U.S., the proportion of women studying physics has been stuck at about $20 \%$ of both bachelor's degrees and doctorates for the past decade, following steady increases in the last third of the 20th century, according to data from the American Physical Society (APS, which publishes Physics). This stagnation has persisted despite many efforts to recruit women and girls into the field. According to studies, the problem is the hostile
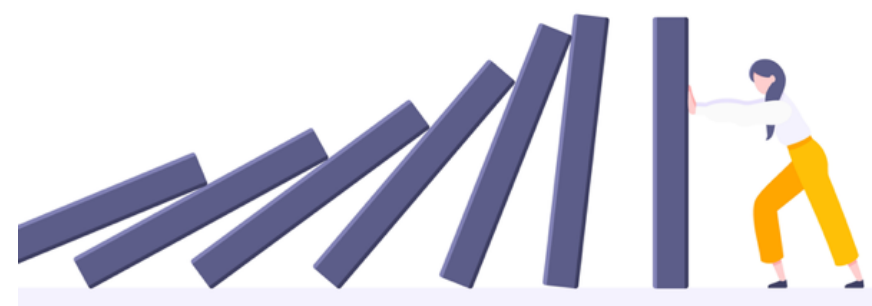

Despite decades of work to make physics more inclusive, many women physicists still struggle to navigate a career path in the field. Credit: Konstantin/stock.adobe.com

\author{
(2) Karina Voggel to \\ @KarinaVoggel
}

Instead of "Advice for being a woman in Science", can we agree to just have "How to not be an asshole that drives women out of science" course for men? I am sick of all the advice. It puts the work on women how to navigate a shitty system made for and by men.

6:52 AM - May 5, 2020 - Twitter Web App

1,114 Retweets 78 Quote Tweets 6,166 Likes

Screenshot of Karina Voggel's 2020 viral tweet that called for an end to conference talks aimed at teaching women how to survive academia.

Credit: @KarinaVoggel/Twitter

environment that drives women from the field after they graduate. So the issue isn't only one of attracting more women to the field-it's keeping them there.

But "survival guide" initiatives, such as the talk Voggel attended, do nothing to change physics' hostile environment. To keep women in the field, Voggel and others would like to see more prominence for diversity programs that create an inclusive physics community than for those that try to help women survive (see Opinion: More than Just a Woman). These programs do exist but are often less visible than conference and university-sponsored talks on topics such as work-life balance or asserting yourself in a male-dominated workspace. Instead of getting women to attend another course on how to get by in 
science, "could we do a course for men [on] how to not be shitty to women in science?" Voggel says, echoing her viral 2020 tweet.

\section{The Culture Issue}

To implement effective diversity programs, researchers agree that it is crucial to understand both why fewer women than men initiate careers in physics and why women drop them at higher rates. Trans, non-binary, and other gender minority physicists are also underrepresented in the field-a 2016 report from the APS on the LGBT+ climate in physics found that half of trans physics students faced harassment in the previous year.

One of the first women to earn an undergraduate physics degree at Yale University, Eileen Pollack, explored the reasons why women are poorly represented in the hard sciences in her 2015 book The Only Woman in the Room: Why Science is Still a Boys' Club. Pollack, who graduated in 1978, did well in classes and in theory projects, but, she says, her insecurities held her back. A lack of confidence was central in her struggles and, she says, is an issue for many other women in the field. If just a single one of her undergraduate lecturers had told her that she could attain her dream of becoming a theoretical physicist, then "I'd be talking to you now as a theoretical physicist," she says.

Students' classroom experiences in introductory physics classes are also often a deciding factor in their decision to pursue physics. Women who find these classes unexpectedly challenging can feel, unduly, like they aren't cut out for physics, says Evie Downie, a nuclear physicist at George Washington University in Washington, D.C. She is past chair of the APS Conferences for Undergraduate Women in Physics (CUWiP), a conference series that brings women students and faculty together to share their experiences. The problem has many roots, including the focus on hundreds-of-years-old discoveries, such as Newtonian mechanics, and the lack of discussion of more recent advances in the field.

Together, these issues can mean that students fail to see real-world applications of physics, says Elizabeth Jensen Young, a video creator for Khan Academy who, until recently, taught physics at Santa Clara University in California. While these issues impact the learning experiences of all students, studies show that they can have a bigger, more "unwelcoming" impact on those who already feel marginalized. In her book, Pollack also criticizes the tendency for problems in classes to revolve around stereotypically masculine objects, such as footballs, guns, and cannons.

\section{What Institutions Can Do}

There are a range of diversity, equity, and inclusion initiatives that focus on cultural changes that institutions are implementing to help women feel that they belong and to make the field much more inclusive. One approach is countering the notion that you have to be white and a man to be a successful physicist. Studies show that when exposed to women physicists, women-and men-are more likely to believe that women can achieve in the field. Constantly being reminded of the archaic "physicists are white men" picture can be exhausting for women and other minorities, Young says. Exposure to physicists who look like you can give you confidence, she adds, something that studies confirm.

One place making concerted efforts to show students more diverse physicists is the physics department at American University (AU) in Washington, D.C. The department has a faculty that consists of $50 \%$ women and a guest speaker list that is gender balanced, says Nate Harshman, who helped achieve those goals when he chaired the department.

Achieving gender balance in conference speakers is a very visible way that the community can promote a commitment to diversity, say advocates. If you're a young woman of color trying to figure out your future, you are unlikely to run and jump into a field that appears to consist of only white men, says the person behind ManelWatchUS, a Twitter account that calls out conference organizers for having all male or all white panels. (The person asked to remain anonymous over concerns of backlash.) But that alone is not enough: it's also important to discuss the reasons why women's involvement in physics has been low historically, Downie says. Research shows that acknowledging the systematic discrimination that led to the current low numbers of women in physics is one of the best ways to keep women in the field. Examples of women physicists through history "aren't all that hard to find," says Leila McNeill, an author of the 2021 book Forces of Nature, The Women Who Changed Science (see Women Scientists Are the Rule Rather Than the Exception). "It is a matter of looking." Women historians have been working for decades to tell the stories of the forgotten women in the field and their contributions, she 
says.

Seeing women role models was a key factor in Mia Villeneuve's decision to stick with physics. "I don't think I would have been able to go into science if I [hadn't seen] any examples of women who had done the same thing," says the undergraduate, who is currently studying at Union College, New York. Villeneuve became aware of women physicists when she attended a networking event for women at the 2019 Division of Nuclear Physics conference in Virginia. Villeneuve says that meeting successful women nuclear physicists removed the invisible wall between herself and a career in physics.

In addition to highlighting women physicists, institutions are also taking steps to shield women from existing biases, ensuring that their ideas get fair consideration. One place where that has been done successfully is the European Southern Observatory (ESO), which this year finished anonymizing its procedure for allocating telescope time. Names have been taken off proposals, and reviewers see only the observational plans. This kind of change requires few resources, Voggel says. She thinks she may have benefitted from the ESO procedure update: Voggel recently had a plan accepted that was previously rejected twice. It could be completely coincidental, she says, "but I feel validated." Voggel adds that the new ESO policy is akin to the practice of observatories providing women's sizes in protective jackets, helmets, and goggles. Feeling included, rather than like an afterthought, can make or break a woman's ability to succeed as a scientist, she says.

Physics departments are also becoming more accommodating to students' needs and are changing their application processes in order to be more welcoming to women. The physics department at $\mathrm{AU}$, for example, prioritized flexibility for its students to help increase diversity, Harshman says. Students can double major, study abroad, and choose the courses that interest them, rather than being forced to follow a rigid schedule. Like updating the content of courses, these options increase the appeal of a physics major to all students, but the numbers at $A U$ show that the changes increase interest in the major more among women. The department also seeks out diverse applicants for its undergraduate program, rather than waiting for them to apply, Harshman says. "Going out and searching for people" who might not think of themselves as qualified or might not envision themselves with a career in

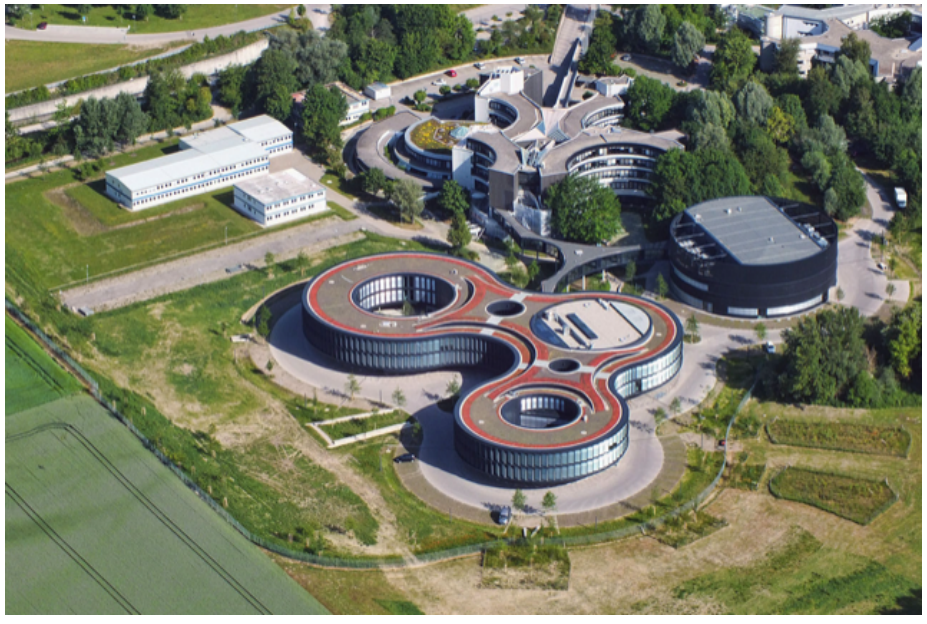

The headquarters of the European Southern Observatory, which recently fully anonymized its process for assessing project proposals for telescope time.

Credit: E. Graf (graf-flugplatz.de)/ESO/Wikimedia Commons

physics can greatly improve diversity, says diversity consultant Dave Collins. He is the founder and CEO of Oak and Reeds, a consulting firm that specializes in making hiring processes more inclusive. "[It] takes time, effort, and money," he says. "But [sometimes] the only way to get more diverse candidates in your pipeline is to go out and find them."

\section{Creating an Inclusive Community}

Another way that institutions are making physics more inclusive is by creating spaces for minority students and staff to come together. Shared communal spaces can make for closer-knit communities and give members a sense of belonging, Harshman says. Being one of only a few women in a department can be isolating. Being a racial minority on top of that can amplify the loneliness, says Elon Price, a second-year master's student in the Fisk-Vanderbilt Bridge Program in Nashville, Tennessee, which helps students transition from master's to Ph.D. programs. Price says that she used to deny to herself that being Black and a woman impacted her physics experience. But, she says, after attending the National Society of Black Physicists (NSBP) conference as an undergraduate, she suddenly felt relief that there were other physicists who looked like her and whose experiences mirrored her own. "[The] isolation was taking a toll on me," she says. "NSBP was the first physics community where I felt welcomed and a sense of 


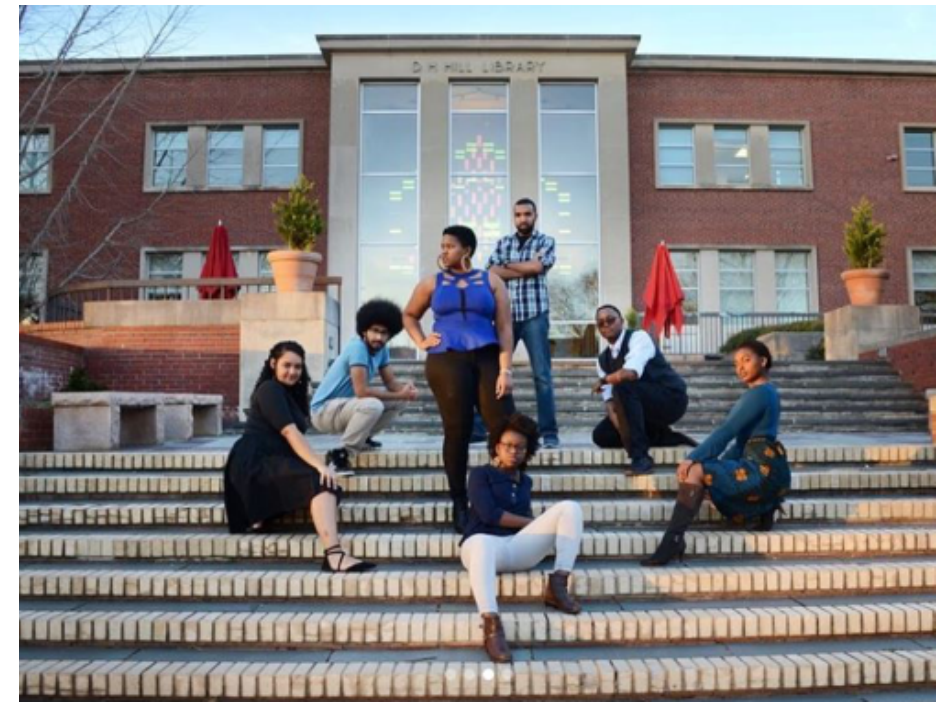

Members of the North Carolina State University 2018-2019 chapter of the National Society of Black Physicists.

Credit: $\mathbf{n s b p}_{n} c s u$ / Instagram

belonging."

Before attending the conference, Price had been tempted to change fields. But, she says, now that she has found her community, she has decided to stay. And she is growing her community. For example, with support from her department, Price helped found an NSBP chapter at North Carolina State University (NCSU) in Raleigh, where she studied as an undergraduate. Price notes that the NCSU chapter had no new Black undergraduate students this academic year, which she and other NSBP chapter leaders attribute to the low number of Black students taking physics as a major. Despite that, she says that the sense of community that she has gained through support from Black peers and mentors has made her feel "more confident to continue on."

Correction (27 July 2021): A figure has been removed from the story at the request of a person shown in the image.

Correction (28 July 2021): A previous version of the story misrepresented the findings of a 2019 American Institute of Physics report on the participation of women in physics. The sentence has been removed.

Leto Sapunar is a freelance science journalist based in Oregon. 